\section{ミカン園における個人灌水 施設の発展とその経済性}

松原盛夫

\section{はじめに}

さいきんにおいて，果樹園における灌水問題は急速 れとりあげられてきたが，その灌水効果の経済性とい った面ではまだ検討の不十分なとてろが残されてい る. これらの問題について、個人灌水施設の実態調查 を行なった．さて灌水効果を論じ る時に二つの立場が考えられるの であるが，その第一の立場を積極 的灌水論とかりに呼ふなならば，第 二の立場は消極的灌水論と屯呼へ るすので，樹体の生長を阻害する 干ばつ時に灌水を行なって，水分 生理をできるだけゆがめない範囲 に補い, 生産物の収量品質の安定 を保とうとする考え方に立つあの であり，私が扱扔うとしているの は，乙の消極的灌水論の立場であ る. 調査地は和歌山県有田郡金屋 町丹生部落で，県下でも個人の灌 水施設としては最も早く設置され たところである.

\section{1. 灌水施設の概況}

丹生部落に灌水施設が最初に設 置されたのは昭和34年で，2戸の 農家の共同によって0.4ha を対象 とした八イプロポンプによるホー ス灌水に始まる．和歌山県下では 有田市の千田東共同灌水事業が始 まったとろである．そのとろ一般 には果樹園灌水に対するひっ迫感 はなかった．しかし昭和 36 年の 7 〜8月の干げつを機会に干田東灌
水事業の成果がかなり大きく報道されるに及んで，急 速に灌水施設への関心が高まり，その年に部落で新し く2 戸の個人灌水施設が導入され，37年の異常干ばつ に遭遇するや，いきおい個人的な灌水施設の設置が促 進されたわけで，37年に新規に.8户が加わり，計12戸 で $3 \sim 4$ haの規模となり，その後毎年数戸ずつ増加し てゆく傾向である．昭和 40 年 1 月の調査ではミカン農 家54戸のうち 24 戸が灌水施設を設置した.

これらの個人灌水施設は一施設当たりで25〜26万円 が標準的なあので，ポンプの能力は，110に/分（36石/ 時間）程度のものが主体である.中には $180 \ell /$ 分から の大型ポンプを使用した70万円もの施設むある。一施 設当たりの灌水対象面積は 0.1 ha から 1 ha とひらきが あるが平均 $0.5 \mathrm{ha}$ で，一戸当たりの灌水実施面積とし ては平均 0.3 ha 程度と非常に小規模であり, 戸別の経 営面積 (ミカン園) に対する灌水実施面積の割合は 1

第 1 表 個人灌水施設の経済性分析（丹生地区昭和 39 年）

\begin{tabular}{|c|c|c|c|c|c|c|}
\hline & 禋 農家番号 & 4 & 5 & 6 & 8 & 10 \\
\hline \multicolumn{2}{|c|}{$10 a$ 当たり施設費 (千円) } & 57.4 & 67.7 & 27.1 & 85.4 & 34.2 \\
\hline & 施 設 費 総 額(千円) & 631.0 & 264.0 & 189.4 & 256.2 & 102.6 \\
\hline (2) & 灌 水 規 模(単位10 $a$ ) & 11 & 3.9 & 7. 0 & 3.0 & 3. 0 \\
\hline \multicolumn{2}{|c|}{$10 a$ 当たり灌水経費(千円) } & 9.50 & 12.00 & 9.18 & 19.76 & 9. 00 \\
\hline \multirow[b]{2}{*}{ 内 } & （1）施 設 償 却 費 & 4. 20 & 5.00 & 2. 90 & 8.50 & 2. 90 \\
\hline & (2) 維 持修䌜費 & 0.80 & 1. 00 & 0.57 & 1. 70 & 0.57 \\
\hline \multirow{3}{*}{$\begin{array}{l}\stackrel{\text { 訳 }}{\text { 干 }} \\
\text { 円 }\end{array}$} & （3）燃 料 費 & 1. 60 & 1. 30 & 2.00 & 3.00 & 1.50 \\
\hline & (4) 人 & 1. 20 & 2. 70 & 2.90 & 4.00 & 3. 00 \\
\hline & （5）資 本 利 子 & 1. 70 & 2. 00 & 0.81 & 2.56 & 1. 03 \\
\hline \multicolumn{2}{|c|}{$1 \mathrm{~kg}$ 当たり灌 水 経 費(円) } & 3. 17 & 5.45 & 3. 28 & 4. 82 & 3. 75 \\
\hline \multicolumn{2}{|c|}{ (1) 灌水後の平均反収(ton) } & 3. 0 & 2.2 & 2. 8 & 4. 1 & 2.4 \\
\hline \multirow{2}{*}{\multicolumn{2}{|c|}{$\begin{array}{l}\text { 機 械 使 用 効 率(\%) } \\
\text { (1) 機械適正負担面積 (ha) }\end{array}$}} & 33 & 20 & 35 & 12 & $\cdots$ \\
\hline & & 3.3 & 2.0 & 2.0 & 2.5 & $\cdots$ \\
\hline \multirow[b]{2}{*}{ 考 } & 昭和 39 年中灌水回数 & 8 & 3 & 3 & 6 & 3 \\
\hline & 水 & $\begin{array}{l}\text { スプリン } \\
\text { クラー }\end{array}$ & $\begin{array}{l}\text { スプリン } \\
\text { クラー }\end{array}$ & $\begin{array}{l}\text { スプリン } \\
\text { クラー }\end{array}$ & $\begin{array}{l}\text { スプリン } \\
\text { クラー }\end{array}$ & $\begin{array}{l}\text { スプリン } \\
\text { クラー }\end{array}$ \\
\hline
\end{tabular}

（注） 1）維持修繥費はそれぞれの耐用期間中に20\%の修理を行なうあの として耐用年数であん分したあのを 1 年間の経費とした。ただ し潤滑油の固定的費用についても算入した.

2）資本利子は施設費の半額に年率 $6 \%$ を掛けて 1 年分とした。

3）人件費はポンプの稼動準備，スプリンクラーの移動，散水見回 り等実際に人力を要した時間数に一時間当たり 150 円を掛けて 算定した。

4) 機械使用効率は機械の適正負担面積（一回散水量 $30 \mathrm{~mm}$ 水深のと き，灌水間断 5 日としてポンプがフルに運転された時の灌水ポ ンプの吐出能力とスプリンクラー取付数との関係からむ求む) に対する灌水対象面積の割合で算出している.

5） 10 番農家の機械使用効率は防除之兼用の場合があるので省略. 
〜2 割の程度から10割までといった開きがみられ，平 均して $3 \sim 4$ 割の範囲にとどまっている.

\section{2. 個人施設の経済性}

個人施設ではその規模から経済効率の面において， かなりの格差が認められるので，問題点を明確にする ため代表的農家の $2 \sim 3$ につい一応分析する.

$10 a$ 当たり年間灌水経費にして 9 千円加 2 万円程 度とかなりのひらきがあり；(第 1 表)，ミカン $1 \mathrm{~kg}$ 当 たり灌水費用は 3 円から 5 円50銭の範囲にある．昭和 39 年の平均手取り単価 $\mathrm{kg}$ 当たり 58 円程度加ら考えれば 5〜10\%の負担にしかならないが，今後ミカンの洒格 次第で問題となるであろう.

参考までに 2 〜 の共同灌水施設との比較をしてお きたい. 第 2 表は共同灌水施設の設置費であるが，単 位面積当たりの経費は一見して丹生地区の個人施設と 大差ない加，むしろ最近計画されている大型灌水施設 では10 $a$ 当たり10万円を上回るあのが多く，ての点で は個人施設のほうが案外安価になっているといえるか あしれない.なお現在の個人施設の大半は機械使用効 率が30\%と低いのであるから，今後の運営の仕方によ っては，なお経費節減の余地があろう。ただし共同灌 水施設は燃料費や人件費に節約的要素があるので， 10 $a$ 当たりの灌水経費は案外高くならないようである.

次に施設の経済効果を灌水効果との関連に扎て分 析をしなければならないが，調査範囲では明確な分析 はできなかった. したがって灌水効果の問題は各地の 試験成績より一般的な傾向を求め, そとから割り出し てみようと思う。

\section{3. 灌水施設の経済効果}

灌水効果については植生上からのいろいろな論議も あるので一概にいえないが，単純に干ばつ時の減収を くいとめる意味での灌水効果に限定して，まずその経 済効果を算定したいと考える.

第 2 表 共同灌水施設の設置費（和歌山県みかん課調へ）

\begin{tabular}{|c|c|c|c|c|c|c|}
\hline 地 区 & 項 目 & 設置年度 & 対象面積 & 総事業額 & $\begin{array}{l}10 a \text { 当た } \\
\text { り設置費 }\end{array}$ & 対象農家数 \\
\hline 和歌山 & 千田東灌水 & 昭和33年 & $43.6^{\text {ha }}$ & 29,470 & $67.3^{\text {千円 }}$ & 56戸 \\
\hline " & 宮原灌 水 & 39 & 65.0 & 80,000 & 123.1 & 148戸 \\
\hline " & 遠方灌 水 & 38 & 46.0 & 50,900 & 110.6 & 83戸 \\
\hline 静 岡 & 清水市但沼 & $36 \sim 38$ & 119.4 & 104,100 & 87.2 & \\
\hline
\end{tabular}

第一に実質的な增収効果として発表された各地の試 験成績を第 3 表によりあげてみた．乙のほかに樹勢の 安定面, 品質向上効果, 着色の促進などもいわれ，さ らに他の技術要素に影響してそれらの総合的な経費節 約といった面であ，経済性は広い関連を示すむのであ るが，それらは後日の問題としておこう.

第 3 表はなんらかの灌水効果があったととを示すす のであり，その程度は 2 割を上回っているものが多い ことが見られるだろう.しかしとの調査年が問題で, 干ばつの激しかった年のものが多いということは注意 しなければならない。参考に広島県での成績(第 4 表) をみても, 灌水効果の程度が干ばつの程度によって最 大50〜60\%から，最少15～20\%の範囲に考えられるよ うである．干ばつ回避の立場からは，刘象園地の従来 可能な平均反収から干ばつによる減収を把握するとと であり，干ばつの程度別に出現年数を考えるととがよ り重要である.

次に経営内部の問題として単位面積当たりの収量の 多少と, 園地の干ばつ被害程度の差が組み合わされて 考えねばならない.また，外的条件としてのミカン価 格の変動もその経済性を大きく左右する．とれらの要 因を解りやすくして，個人施設のそれぞれ個別の経済 効果を採算性を中心として判定しようとしたのが第 1 図の灌水施設の経洛性分析図である。

丹生部落の例では, 反当灌水経費 1 万円程度のとと ろで，価格がkg当たり50円水準として，(4)の農家の場 合反収 $3 \mathrm{t}$ とみたとき，每年 $7 \%$ 以上の増収効果が必 要で， 3 年に一回の干ばつがあって，干ばつ回避の増 收効果が $20 \%$ を上回ってなければ採算点を割ることに なる.

こうした経済効果の見方は灌水効果の最低線をとら えたものであり，1〜2の調査事例にあったように灌 水により従来の平均反収を 5 割から高め得たとなる と, 消極的灌水論の立場だけで論じることはできない であろう。しかし現実に灌水効果をみるとき，単に干 ばつに遭遇したときそれを 補正する灌水として考えた ほうが簡便で，現に丹生部 落での散水状態は干ばつ年 でも 3 〜 回が主体といっ たやり方である. 
第 3 表 灌 水 試 験 の成 績

\begin{tabular}{|c|c|c|c|c|c|}
\hline 場 & 年 & 灌水区収量 & 無灌水区収量 & 增 収率 & 考 \\
\hline 和歌山 果 園 試 & 昭和 $26 \sim 29$ & $55.7^{\mathrm{kg}}$ & $45.2^{\mathrm{kg}}$ & $123.0^{\%}$ & 農業及園芸 \\
\hline 和歌山 千田東灌水 & 36 & 98.6 & 63.5 & 155.3 & 和歌山県みかん課資料 \\
\hline " & 39 & 58.2 & 45.0 & 129.3 & " \\
\hline 香川県 & 37 & $3,532.5$ & $2,062.5$ & 171.2 & 柑橘＼cjkstart第16巻 \\
\hline 山口県大島郡 & $\begin{array}{l}27 \sim 31 \\
32 \sim 34\end{array}$ & 352.5 & 212.2 & 166.1 & " \\
\hline
\end{tabular}

第 4 表 灌 水 $の$ 経済効果(広島県)

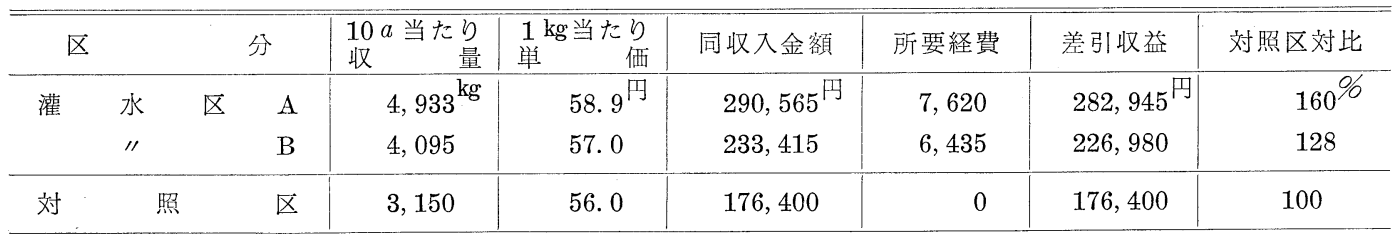

\section{4. 干害問題の究明}

干害問題を考えるとき，地域の降雨量がまず問題之 なる．乙れがミカンの水分生理上必要な水分をおぎな い得るかというととである. との点では土壤の保水力 や樹体の栄養や根の分布状況などが, 根の吸水作用や 有効雨量としての利用量に大きく影響するすのである が，一応とれらの点は考虑外として，単に降雨状況を ミカンの水分要求加の過不足としてとらえてみる.

ミカンの水分要求量についても種々論議はあるが, ここでは鳥潟等が発表したミカンの蒸発量の測定值か ら割出して, 夏のミカン 園の一日の 蒸発量が樹体地 面を合わして水分供給の良いときで 5 ～ $6 \mathrm{~mm}$ といわれ るととから， 1 昍 50〜 60 $\mathrm{mm}$ が標準的雨量として，一 応 $30 \mathrm{~mm}$ 以下を植物の水分生理上支障のあるあのとみな す.とうしたときの旬別出現度合を，和歌山県果樹試 験場の気象データーから，昭和14 39年の 26 年間につ いて整理してみたものが第 5 表である．乙て数年の傾 向加ら出現回数が一定期間内に $50 \%$ を上回るとき，干 ばつ年としてミカンの生産量に影響があったと考えら れるが，過去の反収の変動をミカン生産費調査農家や 個別農家の特定園についてみてあ，必ずしも干ばつと 関係せず，その他の隔年結果性の変動要因が大きく作 用しているようであって減収の程度は計れない，しか し影響あったものとして先の基準で判断すると 26 年間 に11年が干ばつ危険年として現われるのである．ただ
し現実には極端に減収したととは少なく，むしろ干ば つ年が玉太りが悪く，小玉となって商品性が落ちてい たとした場合の経済的損失のほうが大きかったとみる こともできる. この程度は第 6 表のように年により地 域によりその差が大きく，千田東の一例であ 36 年と 39 年とには大きなひらきがあり，39年のごときは灌水を

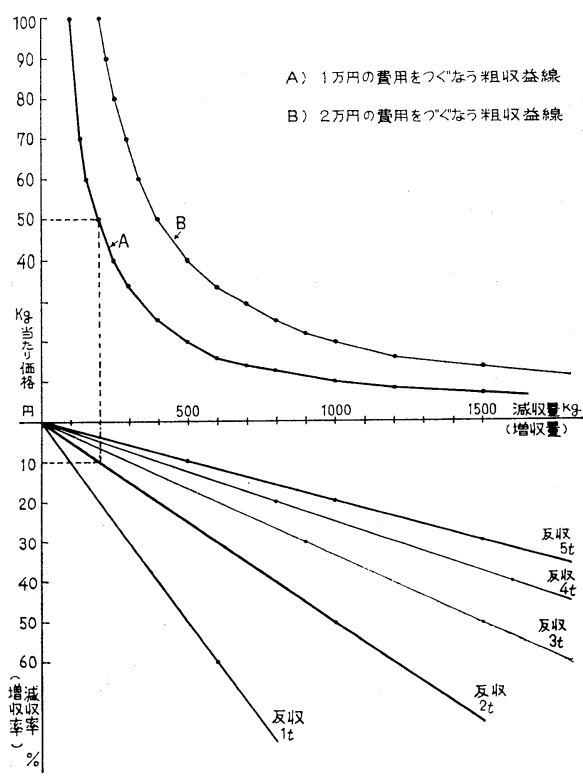

第 1 図 灌水施設の経済性分析図 
第 5 表 旬別降雨量 $30 \mathrm{~mm}$ 以下の出現回数

\begin{tabular}{|c|c|c|c|c|c|c|c|c|c|c|c|c|c|c|c|c|c|c|}
\hline 時期 年度 & 39 & 38 & 37 & 36 & 35 & 34 & 33 & 32 & 31 & 30 & 29 & 28 & 27 & 26 & 25 & 24 & 23 & 22 \\
\hline $7 \sim 8$ 月 & 3 & 3 & 2 & 4 & 2 & 3 & 1 & 1 & 3 & 3 & 3 & 3 & 3 & 4 & 1 & 1 & 3 & 2 \\
\hline $9 \sim 11$ 月 & 5 & 4 & 7 & 3 & 5 & 3 & 3 & 3 & 4 & 4 & 5 & 6 & 4 & 2 & 3 & 1 & 4 & 6 \\
\hline $6 \sim 11$ 月 & 9 & 8 & 9 & 8 & 7 & 8 & 5 & 5 & 7 & 8 & 8 & 9 & 7 & 6 & 4 & 2 & 8 & 10 \\
\hline 時期 & 21 & 20 & 19 & 18 & 17 & 16 & 15 & 14 & & & & & & & & & & \\
\hline $7 \sim 8$ 月 & 2 & 3 & 5 & 3 & 4 & 2 & 2 & 4 & & & & & & & & & & \\
\hline $9 \sim 11$ 月 & 3 & 3 & 2 & 6 & 5 & 4 & 6 & 5 & & & & & & & & & & \\
\hline $6 \sim 11$ 月 & 5 & 6 & 8 & 10 & 9 & 6 & 9 & 10 & & & & & & & & & & \\
\hline
\end{tabular}

注）太字は一定期間内で出現度数が50\%を上回る数字

第 6 表 階 級 差による 灌 水効 果

\begin{tabular}{|c|c|c|c|c|c|c|c|c|}
\hline \multirow{2}{*}{ 場 } & \multirow{2}{*}{ 年 度 } & 灌 & 水 & 区 & 無 & \multicolumn{2}{|l|}{ 灌 水 } & \multirow{2}{*}{$\begin{array}{c}\text { MI 上率比 } \\
\text { (灌水/㷏灌水) }\end{array}$} \\
\hline & & $\mathrm{M}$ 上 & S 下 & 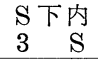 & $\mathrm{M}$ 上 & S 下 & $\begin{array}{l}\text { S 下内 } \\
3 \text { S }\end{array}$ & \\
\hline 千田東灌 水 & 昭和 36 年 & $84 \%$ & $16 \%$ & & $78 \%$ & $22 \%$ & & 107.7 \\
\hline " & 39 & 30.8 & 69.2 & 6.8 & 7.1 & 92.9 & 28.8 & 433.8 \\
\hline 竜 門 灌 水 & 39 & 36.3 & 63.7 & 4.4 & 8.9 & 91.1 & 15.5 & 407.8 \\
\hline 和歌山果試 & 26 & 41.5 & 58.5 & & 25.6 & 74.4 & & 162.1 \\
\hline \multirow[t]{2}{*}{ 広 島 県 } & 36 & 71.1 & 28.9 & & 55.4 & 44.6 & & 128.3 \\
\hline & 37 & 80.0 & 20.0 & & 48.6 & 51.4 & & 164.4 \\
\hline
\end{tabular}

注） $\mathrm{M}$ 上率比とは $\mathrm{M}$ 級以上（ $\mathrm{M} ， 2 \mathrm{~L} ， 3 \mathrm{~L}$ 階級）の全階級数量に対する比率での無灌水区に 対する灌水の比較

しながら M上率が30\%そこそこであるのは，その年の 結果量に大きく左右されているあのと判断されるし, 地域性の認められるのは結果量ととあに土壤条件が問 題であろう.

灌水効果は干ばつ年には大きく期待できることは明 らかであるが，割合軽い干ばつに対しては他の樹体条 件の整備によって補い得る面ああって, 今後土壤深耕 による根の深層への到達, 有機質の施用による土壇改 良が土壤の保水性を高め根量を増加することができ, 摘果による樹勢の安定が考えられるならば，干ばつを ある程度回避するととあできよう。

\section{5. ま と め}

最後に丹生部落の問題に限って個人灌水施設の経済 性についてまとめておきたい。. 3 年に一度 3 割減収程 度の干ばつがあり，それを完全に回避したとした時の
経済効果から施設の採算点を割り出すとすれば，平均 反収を $3 \mathrm{t}$ とした場合，ミカンの価格がkg当たり50円 ならば，反当灌水経費が 15,000 円までは採算性がある ことになり，現在の個人施設もまずまずの採算点内に あった．しかし現在の反当灌水経費を軽減するとなれ ば個人的施設のほとんどが $30 \%$ 程度の機械使用効率に しかなっていないので，今後一施設当たり $1.5 \mathrm{ha}$ の規 模を目標に共同化の方向をさぐるべきである.

今後の大規模共同灌水施設については，期待してい るむきあありながら，一方では現状の個人施設に満足 している状態であある.個人施設は何よりも個別に気 楽にやれるというととと, 自己の労力や資本利子の評 価をしない一般的な農家の傾向から考え，またいまだ にミカンの個人選果が存続する経営形態の中で, 意識 的にも共同化をはばむ要因があるとみなければならな い現状である。 